\title{
ARAH KEBIJAKAN RAJA PADA MASA JAWA KUNO PASCA PERISTIWA PRALAYA DARI SUDUT PANDANG TEORI KONTRAK SOSIAL
}

\author{
Policy Direction of Ancient Javanese Kings in Post-Pralaya Event from Contract \\ Social Theory Perspective
}

\author{
Muhamad Alnoza \\ Alumni Program Studi Arkeologi, Fakultas Ilmu Pengetahuan Budaya UI \\ Jalan Selo Soemardjan, Kampus UI, Depok, Jawa Barat \\ E-mail: muhamadalnoza@gmail.com
}

\begin{abstract}
The apocalypse or the end of the world in Hindu-Buddhist culture is known as pralaya. The concept of pralaya is related to one of the cycles of time in Hindu-Buddhist beliefs, namely Kaliyuga. The existence of pralaya as a disaster caused a fundamental change to power in Java in the past. This paper specifically raises the issue of what policies issued by a post-pralaya king. The purpose of this study is to determine the direction of the post-pralaya king's policies as a disaster or doomsday from a religious perspective. This paper takes the example of King Sindok and Airlangga as a comparison of the kings who came to power after pralaya. Archaeological methods are used to address this problem. The method consists of data collection, analysis and interpretation. This series of research resulted in an understanding that the two kings had directly or indirectly claimed to be Lord Vishnu, who was saved from pralaya, so that the people had the right to safety and prosperity after pralaya through policies issued by the king, either in the form of development or protection.
\end{abstract}

Keywords: Airlangga, contract social, disaster, pralaya, Sindok

\begin{abstract}
Abstrak
Kiamat atau akhir dari dunia dalam kebudayaan Hindu-Buddha dikenal sebagai pralaya. Konsep pralaya berkaitan dengan salah satu siklus zaman dalam kepercayaan Hindu-Buddha, yaitu zaman Kaliyuga. Keberadaan pralaya sebagai bencana menyebabkan suatu perubahan mendasar bagi kekuasaan di Jawa pada masa lampau. Tulisan ini secara khusus mengangkat permasalahan mengenai kebijakan apa yang dikeluarkan oleh seorang raja pasca pralaya. Tujuan dari penelitian ini adalah mengetahui arah kebijakan raja pasca-pralaya sebagai bencana atau kiamat dalam sudut pandang kontrak sosial. Tulisan ini menjadikan contoh Raja Sindok dan Airlangga sebagai perbandingan raja yang berkuasa pasca pralaya. Metode arkeologi digunakan untuk menjawab permasalahan ini. Metode tersebut terdiri dari pengumpulan data, analisis dan interpretasi. Rangkaian penelitian tersebut menghasilkan suatu pemahaman bahwa kedua raja secara langsung maupun tidak telah mengklaim diri sebagai Dewa Wisnu yang selamat dari pralaya, sehingga rakyat berhak mendapatkan keselamatan dan kemaslahatan pasca pralaya melalui kebijakan-kebijakan yang dikeluarkan oleh sang raja, baik berupa pembangunan ataupun pelindungan.
\end{abstract}

Kata kunci: Airlangga, bencana, kontrak sosial, pralaya, Sindok

\section{PENDAHULUAN}

Salah satu konsep kiamat yang berkembang (khususnya di Indonesia) adalah konsep pralaya. Pralaya merupakan suatu konsep dari suatu kepercayaan akan kehancuran masif dunia pada masa Kaliyuga. Konsep ini berkaitan erat dengan 
kepercayaan Hindu atas siklus sejarah yang terus bergerak (Wibowo, 2014). Pralaya dipandang sebagai penutup dari suatu siklus dan pengawal dari suatu siklus yang baru (kembali lagi pada Kertayuga) (Moniz, 2015). Peristiwa ini digambarkan sebagai sebuah keadaan dunia yang telah kehilangan keseimbangannya. Kehilangan keseimbangan ini diwujudkan dalam bentuk bencana alam dan bencana sosial (Schrieke, 2016).

Peristiwa Pralaya agaknya menjadi suatu titik penting dalam sejarah perjalanan kehidupan masyarakat Jawa. B.J.O. Schrieke (2016) menyebutkan bahwa orang Jawa meyakini bahwa tiap dinasti atau kerajaan yang berdiri di Jawa pasti akan mengalami pralaya dan menumbuhkan suatu dinasti baru yang membawa kebahagiaan bagi umat manusia. Eksistensi pralaya ini setidaknya menghantarkan kepada suatu isu mengenai raja yang memerintah pada masa pasca-pralaya di zaman Jawa Kuno. Dasar dari isu ini berasal dari suatu kutipan kitab Agastyaparwa yang berbunyi: "Ketika keempat tahap kehidupan dan keempat kasta telah berjalan baik dan memuaskan, maka umat manusia akan bahagia, dan begitu pula dunia. Hanya dengan demikianlah Yang Mulia Raja, dan seluruh keluarga beserta keturunannya, akan meraih kemenangan dan bebas dari penderitaan" (Gonda, 1936; Schrieke, 2016).

Raja sebagaimana yang digambarkan dalam kutipan tersebut merupakan seorang "juru selamat" akhir zaman yang akan membawa kesejahteraan, kebahagiaan dan zaman baru bagi rakyatnya. Raja dengan demikian memegang peranan penting dalam memanfaatkan keadaan yang kacau sebelumnya sebagai legitimasi kekuasaannya. Premis ini erat kaitannya dengan Teori Kekuasaan dan Bencana, yang secara gamblang menjelaskan mengenai kaitan kekuasaan dengan kemaslahatan masyarakat pascabencana. Penguasa menawarkan "ganti rugi" bagi masyarakat yang menderita bencana dan sebagai gantinya penguasa tersebut mendapatkan legitimasi bagi kekuasaannya (Mascarenhas \& Wisner, 2012).

Berkaitan dengan serangkaian pemikiran tersebut, kajian ini berusaha untuk menjelaskan bagaimana cara seorang raja yang berkuasa pasca-pralaya pada masa Jawa Kuno dalam menghadapi rakyatnya yang menderita setelah mengalami "kiamat" serta memanfaatkan momen tersebut dalam memperkuat legitimasinya. Cara yang diaplikasikan oleh sang raja pada akhirnya dapat diketahui melalui kebijakan yang dikeluarkan bagi rakyatnya, sehingga tujuan lain dari penelitian ini adalah untuk mengetahui arah kebijakan yang dikeluarkan oleh sang raja. Kedua tujuan penelitian tersebut dituangkan ke dalam satu rumusan masalah, yaitu apa kebijakan yang dikeluarkan oleh raja yang berkuasa pasca-pralaya?

Rumusan masalah di atas diaplikasikan pada dua kasus raja yang berkuasa pasca- pralaya yang berlangsung pada masa Jawa Kuno, yaitu Śrī Maharaja Rake Hino Mpu Sindok Sri Isanawikrama Dharmmotunggadewa (selanjutnya disingkat menjadi Raja Sindok) dan Śrī Maharaja Rakai Halu Śrī Lokeswara Dharmmawangsa Airlangga Anantawikramotunggadewa (selanjutnya disingkat menjadi Raja Airlangga). Kedua raja dipilih menjadi kasus merujuk pada dua pertimbangan, antara lain keduanya merupakan raja yang berasal dari satu keluarga, sebagaimana yang dicatat dalam Prasasti Pucangan 
Sansekerta yang berangka tahun 1037 M (Susanti, 2010) sehingga diharapkan konsep pralaya yang dianut oleh keduanya tidak jauh berbeda. Kedua raja berkuasa pascapralaya dengan detil peristiwa yang berbeda. Raja Sindok berkuasa pasca-pralaya yang berupa bencana alam (Boechari, 2012b; van Bemmelen, 1949), sedangkan Airlangga berupa bencana sosial (Susanti, 2010).

Metode yang digunakan dalam menjawab rumusan masalah penelitian ini adalah metode penelitian arkeologi. Metode ini terdiri dari tahapan pengumpulan data, analisis dan interpretasi (Gibbon, 2013). Pengumpulan data dilakukan melalui penelusuran hasil alihaksara dan alihbahasa kedua prasasti. Data sekunder yang dikumpulkan dalam kajian ini adalah sejarah pralaya yang berlangsung sebelum Raja Sindok dan Airlangga memerintah. Analisis dilakukan terhadap data melalui penentuan angka tahun serta ringkasan informasi sejarah yang dimuat dalam prasasti. Data yang yang telah dianalisis kemudian diinterpretasi melalui paradigma Teori Kontrak Sosial yang dikemukakan oleh J.J. Rousseau. Teori ini melihat dalam suatu negara, terdapat semacam pertukaran antara penguasa dan rakyatnya. Penguasa dalam tataran ini menawarkan jawaban terhadap "cita-cita bersama" (general will), sedangkan rakyat menawarkan kesetiaan serta legitimasi (Economides, 2019).

\section{PEMBAHASAN}

\section{Data}

Prasasti yang digunakan sebagai data dalam kajian ini merupakan sebagian prasasti yang dikeluarkan oleh Raja Sindok dan Airlangga. Prasasti yang dipilih sebagai data merupakan prasasti yang berangka tahun, terdapat kajian alihaksara dan alihbahasa sebelumnya, serta memuat peristiwa sejarah yang mewakili kebijakan sang raja (tabel 1 dan tabel 2).

\begin{tabular}{|c|c|c|c|}
\hline No. & Nama Prasasti & Angka Tahun & Ikhtisar Isi \\
\hline 1. & $\begin{array}{l}\text { Prasasti } \\
\text { Cunggrang I }\end{array}$ & $929 \mathrm{M}(851 \mathrm{~S})$ & $\begin{array}{l}\text { Penetapan wilayah Desa Cunggrang sebagai tanah sima yang } \\
\text { diperuntukkan bagi bangunan suci. Bangunan suci ini diperuntukkan } \\
\text { bagi mertua Sindok (Rakryān Bawan) yang telah diperdewatakan di } \\
\text { Pawitra (Damais, 1955; Pardede, 1986; Poesponegoro \& } \\
\text { Notosusanto, 2010) }\end{array}$ \\
\hline 2. & $\begin{array}{l}\text { Prasasti } \\
\text { Cunggrang II }\end{array}$ & $929 \mathrm{M}(851 \mathrm{~S})$ & Isinya sama dengan Prasasti Cunggrang I \\
\hline 3. & $\begin{array}{l}\text { Prasasti } \\
\text { Linggasuntan }\end{array}$ & 929 & $\begin{array}{l}\text { Penetapan Desa Linggasuntan yang merupakan wilayah Rakryān } \\
\text { Hujuy menjadi daerah sima untuk pembangunan suci yang } \\
\text { diperuntukkan bagi Bhațāra i Walaṇdit (Damais, 1955; } \\
\text { Poesponegoro \& Notosusanto, 2010; Wurjantoro, 2018) }\end{array}$ \\
\hline 4. & $\begin{array}{l}\text { Prasasti } \\
\text { Rinting }\end{array}$ & $929 \mathrm{M}(8$ & $\begin{array}{l}\text { Penetapan daerah sima di Poh Rintiy bagi sebuah kabikuān (Damais, } \\
\text { 1955; Susanti, 2010) }\end{array}$ \\
\hline 5. & $\begin{array}{l}\text { Prasasti } \\
\text { Sarangan }\end{array}$ & $929 \mathrm{~N}$ & $\begin{array}{l}\text { Penetapan daerah Desa Sarangan sebagai daerah sima (Damais, } \\
\text { 1955; Wurjantoro, 2018) }\end{array}$ \\
\hline 6. & Prasasti Turryān & $929 \mathrm{M}(851 \mathrm{~S})$ & $\begin{array}{l}\text { Penetapan sebidang tanah di Desa Turyyān sebagai bangunan suci } \\
\text { sekaligus juga penugasan kerja bakti bagi penghuni desa tersebut } \\
\text { dalam membangun bendungan (Damais, 1955; Poesponegoro \& } \\
\text { Notosusanto, 2010) }\end{array}$ \\
\hline 7. & $\begin{array}{l}\text { Prasasti } \\
\text { Gulung-gulung }\end{array}$ & $929 \mathrm{M}(851 \mathrm{~S})$ & $\begin{array}{l}\text { Penetapan hutan di Bantaran sebagai daerah sima yang digunakan } \\
\text { sebagai tempat persembahan bagi Say hyay i pangawan (Damais, } \\
1955 \text {; Pardede, 1986; Poesponegoro \& Notosusanto, 2010; } \\
\text { Wurjantoro, 2018) }\end{array}$ \\
\hline 8. & Prasasti Waharu & $929 \mathrm{M}(851 \mathrm{~S})$ & Penetapan daerah dharmma sima atas tanah milik Rakryān \\
\hline
\end{tabular}




\begin{tabular}{|c|c|c|c|}
\hline & II & & $\begin{array}{l}\text { Mahāmantri Pu Sahașra. Anugrah ini terus berlaku bagi seluruh } \\
\text { keturunannya (Damais, 1955; Pardede, 1986) }\end{array}$ \\
\hline 9. & Prasasti Jru-jru & $930 \mathrm{M}(852 \mathrm{~S})$ & $\begin{array}{l}\text { Penetapan Desa Jru jru sebagai tanah sima untuk bangunan suci. } \\
\text { Bangunan suci ini diperuntukkan bagi Rakryān Hujuy dalam memuja } \\
\text { Say Śăla (Poesponegoro \& Notosusanto, 2010; Wurjantoro, 2018) }\end{array}$ \\
\hline 10. & $\begin{array}{l}\text { Prasasti Waharu } \\
\text { IV }\end{array}$ & $931 \mathrm{M}(853 \mathrm{~S})$ & $\begin{array}{l}\text { Penetapan wilayah Desa Waharu sebagai tanah sima karena rakyat di } \\
\text { sana telah setia pada Raja Sindok (Damais, 1955; Pardede, 1986; } \\
\text { Susanti, 2010) }\end{array}$ \\
\hline 11. & Prasasti Sumbut & $933 \mathrm{M}(855 \mathrm{~S})$ & $\begin{array}{l}\text { Penetapan Desa Sumbut sebagai sima karena jasa rakyat desa } \\
\text { tersebut telah membantu raja menghalau musuh (Damais, 1955; } \\
\text { Poesponegoro \& Notosusanto, 2010; Susanti, 2010) }\end{array}$ \\
\hline 12. & Prasasti Geweg & $933 \mathrm{M}(855 \mathrm{~S})$ & $\begin{array}{l}\text { Penetapan desa Geweg sebagai sima oleh permaisuri Raja Sindok } \\
\text { (Brandes, 1913; Damais, 1955; Poesponegoro \& Notosusanto, 2010) }\end{array}$ \\
\hline 13. & Prasasti Hering & $934 \mathrm{M}(856 \mathrm{~S})$ & $\begin{array}{l}\text { Penetapan Desa Hering sebagai tanah sima oleh Raja Sindok melalui } \\
\text { Rakai Kanuruhan Pu Tã. Tanah sima digunakan untuk pembinaan } \\
\text { Wihara (Damais, 1955; Pardede, 1986; Susanti, 2010; Wurjantoro, } \\
\text { 2018) }\end{array}$ \\
\hline 14. & $\begin{array}{l}\text { Prasasti } \\
\text { Kanuruhan }\end{array}$ & $935 \mathrm{M}(857 \mathrm{~S})$ & $\begin{array}{l}\text { Penetapan sebidang sawah di desa yang masuk wilayah Kanuruhan } \\
\text { sebagai sima. yang nantinya diperuntukan bagi kebun bunga } \\
\text { (Damais, 1955; Poesponegoro \& Notosusanto, 2010; Susanti, 2010) }\end{array}$ \\
\hline 15. & Prasasti Wulig & $935 \mathrm{M}(857 \mathrm{~S})$ & $\begin{array}{l}\text { Perintah Rakryān Binihaji Rakryān Manibil (istri Sindok) kepada } \\
\text { warga Desa Wulig untuk membangun bendungan (Damais, 1955; } \\
\text { Poesponegoro \& Notosusanto, 2010) }\end{array}$ \\
\hline 16. & $\begin{array}{l}\text { Prasasti } \\
\text { Aňjukladang }\end{array}$ & $937 \mathrm{M}(859 \mathrm{~S})$ & $\begin{array}{l}\text { Penetapan daerah sawah kakațikan di Aňjukladang sebagai daerah } \\
\text { sima bagi bangunan suci yang dipersembahkan untuk Say hyay } \\
\text { Prasada Kabaktyan i Śrī Jayamerta (Damais, 1955; Pardede, 1986; } \\
\text { Poesponegoro \& Notosusanto, 2010; Wurjantoro, 2018) }\end{array}$ \\
\hline 17. & $\begin{array}{l}\text { Prasasti } \\
\text { Sobhamerta }\end{array}$ & $939 \mathrm{M}(861 \mathrm{~S})$ & $\begin{array}{l}\text { Penetapan anugrah sima terhadap sebidang sawah di Desa } \\
\text { Sobhamerta dalam rangka pembangunan dan pemeliharaan wihara } \\
\text { (Pardede, 1986; Susanti, 2010) }\end{array}$ \\
\hline 18. & $\begin{array}{l}\text { Prasasti } \\
\text { Alasantan }\end{array}$ & $939 \mathrm{M}(861 \mathrm{~S})$ & $\begin{array}{l}\text { Penetapan Desa Alasantan sebagai sima yang diperuntukkan bagi } \\
\text { ibunda Rakryān Mapatih i Halu Dyah Sahaśra (Pardede, 1986) }\end{array}$ \\
\hline 19. & $\begin{array}{l}\text { Prasasti } \\
\text { Kamban }\end{array}$ & $941 \mathrm{M}(863 \mathrm{~S})$ & $\begin{array}{l}\text { Pentapan daerah sima di Desa Kamban oleh Raja Sindok melalui } \\
\text { Rakryān Kanuruhan (Damais, 1955) }\end{array}$ \\
\hline 20. & $\begin{array}{l}\text { Prasasti Paradah } \\
\text { I }\end{array}$ & $943 \mathrm{M}(865 \mathrm{~S})$ & $\begin{array}{l}\text { Penetapan sebidang sawah di Desa Paradah sebagai sima bagi } \\
\text { bangunan suci kabikuan (Damais, 1955; Pardede, 1986; } \\
\text { Poesponegoro \& Notosusanto, 2010; Susanti, 2010) }\end{array}$ \\
\hline 21. & $\begin{array}{l}\text { Prasasti Paradah } \\
\text { II }\end{array}$ & $943 \mathrm{M}(865 \mathrm{~S})$ & $\begin{array}{l}\text { Penetapan sebuah sawah di utara sungai di Desa Paradah sebagai } \\
\text { tanah sima (Damais, 1955; Pardede, 1986) }\end{array}$ \\
\hline 22. & $\begin{array}{l}\text { Prasasti } \\
\text { Muňcang }\end{array}$ & $944 \mathrm{M}(866 \mathrm{~S})$ & $\begin{array}{l}\text { Penetapan sebidang tanah di selatan pasar di Desa Muňcang sebagai } \\
\text { tanah sima yang diperuntukan bagi bangunan suci bernama } \\
\text { Siddhayoga (Damais, 1955; Pardede, 1986; Poesponegoro \& } \\
\text { Notosusanto, 2010) }\end{array}$ \\
\hline 23. & $\begin{array}{l}\text { Prasasti } \\
\text { Wuradungan I }\end{array}$ & $948 \mathrm{M}(870 \mathrm{~S})$ & $\begin{array}{l}\text { Penetapan seluruh daerah Kanuruhan sebagai daerah sima yang } \\
\text { diperuntukkan bagi bangunan suci persembahan untuk Sayhyay } \\
\text { Dharmma Kahyayan } i \text { Wuranduyan (Damais, 1955; Pardede, 1986) }\end{array}$ \\
\hline
\end{tabular}

Tabel 1. Prasasti yang berkaitan dengan Kebijakan Raja Sindok (929-948 M).

\begin{tabular}{|c|c|c|c|}
\hline No. & Nama Prasasti & Angka Tahun & Ikhtisar Isi \\
\hline 1. & Prasasti Cane & $1021 \mathrm{M}(943 \mathrm{~S})$ & $\begin{array}{l}\text { Penetapan Desa Cane sebagai sima karaman untuk membalas jasa } \\
\text { warga desa yang membantu Airlangga selama bertapa untuk } \\
\text { mempersiapkan diri menjadi raja (Susanti, 2010) }\end{array}$ \\
\hline 2. & $\begin{array}{l}\text { Prasasti } \\
\text { Munggut }\end{array}$ & $1022 \mathrm{M}(944 \mathrm{~S})$ & $\begin{array}{l}\text { Pemberian anugrah sima oleh Airlangga kepada Desa Munggut } \\
\text { karena jasa seseorang bernama kakek Gamala yang membantu } \\
\text { Airlangga dalam menyelamatkan diri dari Wwuatan Mas (Susanti, } \\
\text { 2010) }\end{array}$ \\
\hline 3. & $\begin{array}{l}\text { Prasasti } \\
\text { Kakurugan I }\end{array}$ & $1023 \mathrm{M}(945 \mathrm{~S})$ & $\begin{array}{l}\text { Pemberian anugrah berupa tanah sima beserta hak-hak istimewa } \\
\text { kepada Dyah Kaki Ngadulengen yang baktinya terhadap raja amat } \\
\text { luar biasa (Susanti, 2010) }\end{array}$ \\
\hline 4. & Prasasti Baru & $1030 \mathrm{M}(952 \mathrm{~S})$ & $\begin{array}{l}\text { Penetapan Desa Baru sebagai wilayah sima karena jasa warganya } \\
\text { yang telah memberi tempat berlindung bagi raja ketika berperang }\end{array}$ \\
\hline
\end{tabular}




\begin{tabular}{|c|c|c|c|}
\hline & & & $\begin{array}{l}\text { melawan Raja Hasin. Bantuan ini menyebabkan raja menang } \\
\text { melawan Raja Hasin (Djafar, 2016) }\end{array}$ \\
\hline 5. & Prasasti Terep I & $1032 \mathrm{M}(954 \mathrm{~S})$ & $\begin{array}{l}\text { Penetapan sebuah pertapaan di Terep sebagai wilayah sima beserta } \\
\text { pula pemberian hak istimewa bagi Rakĕ Pankaja Dyah Tumambong } \\
\text { yang berdoa kepada bhatari ketika Airlangga melarikan diri ke } \\
\text { Patakan (Susanti, 2010) }\end{array}$ \\
\hline 6. & $\begin{array}{l}\text { Prasasti } \\
\text { Pucangan } \\
\text { Sansekerta }\end{array}$ & 1037 M (959 S) & $\begin{array}{l}\text { Silsilah Raja Airlangga serta urutan peristiwa penyerangan yang } \\
\text { dilakukannya terhadap Raja Wura-Wari, Raja Wěngkēr dan Raja } \\
\text { Hasin sejak tahun 1029 M hingga 1037 M (Witasari, 2009) }\end{array}$ \\
\hline 7. & $\begin{array}{l}\text { Prasasti } \\
\text { Kamalagyan }\end{array}$ & 1037 M (959 S) & $\begin{array}{l}\text { Penetapan Desa Kamalagyan sebagai wilayah sima dalam rangka } \\
\text { pemeliharaan Bendungan Waringin Sapta (Susanti, 2010) }\end{array}$ \\
\hline 8. & $\begin{array}{l}\text { Prasasti } \\
\text { Turunhyang A }\end{array}$ & $1036 \mathrm{M}(958 \mathrm{~S})$ & $\begin{array}{l}\text { Penetapan tanah sima di Desa Turunhyang dalam rangka } \\
\text { pembangunan pertapaan bagi Cakravartin (Airlangga) yang tiada } \\
\text { lagi memiliki musuh (Susanti, 2010) }\end{array}$ \\
\hline 9. & $\begin{array}{l}\text { Prasasti } \\
\text { Pucangan Jawa } \\
\text { Kuno }\end{array}$ & $1041 \mathrm{M}(963 \mathrm{~S})$ & $\begin{array}{l}\text { Penetapan tiga desa sekaligus (Barahem, Pucangan dan Cepuri) } \\
\text { sebagai wilayah sima, yang didasarkan pada sumpah raja ketika } \\
\text { adanya peristiwa pralaya. Prasasti ini juga menceritakan perihal } \\
\text { invasi-invasi yang dilakukan oleh Airlangga kepada para musuhnya } \\
\text { hingga puncak takluknya Pulau Jawa pada tahun } 1041 \text { (Susanti, } \\
\text { 2010; Witasari, 2009) }\end{array}$ \\
\hline 10. & Prasasti Pandan & $1042 \mathrm{M}(964 \mathrm{~S})$ & Penetapan Desa Pandan sebagai wilayah sima (Susanti, 2010) \\
\hline 11. & $\begin{array}{l}\text { Prasasti } \\
\text { Gandhakuti }\end{array}$ & $1042 \mathrm{M}(964 \mathrm{~S})$ & $\begin{array}{l}\text { Penetapan sebuah bangunan suci di Desa Kambang Sri sebagai sima } \\
\text { yang nantinya diperuntukkan bagi anak Airlangga sendiri. Di } \\
\text { prasasti ini Airlangga telah digelari dengan Aji Paduka Mpungku } \\
\text { yang menandakan kedudukannya yang memasuki masa akhir } \\
\text { kekuasaan (Susanti, 2010) }\end{array}$ \\
\hline 12. & $\begin{array}{ll}\text { Prasasti } & \text { Pasar } \\
\text { Legi }\end{array}$ & $1043 \mathrm{M}(965 \mathrm{~S})$ & $\begin{array}{l}\text { Pemberian anugrah (tidak dikehui jenis anugrahnya karena bagian } \\
\text { ini tidak terbaca) oleh Raja Airlangga kepada Desa Patakan. Alasan } \\
\text { pemberian anugerah adalah karena diperkirakan warga desa tersebut } \\
\text { membantu Airlangga selama pelariannya dari kalah perang di } \\
\text { Keraton Wwuatan Mas (Susanti, 2010) }\end{array}$ \\
\hline
\end{tabular}

Tabel 2. Prasasti yang berkaitan dengan Kebijakan Raja Airlangga (1021-1043).

\section{Pralaya Masa Raja Sindok dan Airlangga}

Pralaya pada masa pra-kekuasaan Raja Sindok sebenarnya tidak benar-benar jelas ditemukan dalam data arkeologi atau pun sejarah. Dasar utama teori pralaya pada pra-kekuasaan Sindok bersumber dari kenyataan bahwa Sindoklah raja yang memindahkan pusat kekuasaan dari Jawa Tengah ke Jawa Timur serta membangun dinasti baru bernama Dinasti Isana karena letusan gunung (Poesponegoro \& Notosusanto, 2010). Perpindahan Kerajaan Mataram Kuno dalam teori beberapa peneliti sebelumnya dikaitkan dengan letusan Gunung Merapi yang menyebabkan pergeseran tanah dan terbenturnya lempeng sekitar Magelang. Peristiwa ini diikuti dengan gempa, banjir lahar dingin, longsor, dan awan panas yang menghancurkan peradaban di Jawa Tengah (Andreastuti, 2006; van Bemmelen, 1949)

Pralaya pada masa pra-kekuasaan Airlangga dengan amat jelas dapat ditemui pada Prasasti Pucangan Sansekerta (1037) Jawa Kuno (1041). Airlangga dikisahkan pada tahun 1017 M (939 Saka) telah mengalami mahapralaya, yaitu ketika Haji Wura Wari yang merupakan seorang raja bawahan dari Lwaram menyerbu kraton sehingga membinasakan kerajaan beserta raja dan putrinya. Penyerangan ini menyebabkan kehancuran luar biasa, yang seakan-akan meluluhlantakkan Pulau Jawa. Airlangga 
kemudian tinggal di hutan untuk bertapa dan berdoa pada para dewa. Kedekatannya pada para dewa, menyebabkan Airlangga direstui oleh para pendeta Siwa, biksu Buddha dan para Mahābrahmana menjadi seorang raja pada tahun 1019 M (Poesponegoro \& Notosusanto, 2010)

\section{Interpretasi}

Kebijakan yang dikeluarkan oleh kedua raja memiliki beberapa unsur yang berbeda satu sama lain. Raja Sindok menggambarkan dirinya sebagai seorang konstruktor infrastruktur, baik di bidang keagamaan dan sosial kemasyarakatan. Kebijakan pembangunan di bidang keagamaan dalam hal ini dapat dilihat dari kebijakan penetapan sima punpunan, baik bagi Agama Buddha dan Saiwa. Sima punpunan dalam hal ini merupakan wilayah sima yang diperuntukkan bagi suatu bangunan keagamaan (Darmosoetopo, 1997). Kebijakan ini agaknya menjadi kebijakan yang paling sering dikeluarkan oleh Sindok. Pernyataan ini didapat dari keseluruhan jumlah prasasti yang menjadi data, terdapat 13 prasasti yang berisi perihal penetapan sima punpunan. Kebijakan sosial kemasyarakatan dapat dilihat dari keberadaan prasasti yang berisi soal anugrah sima makudur atau sima yang diberikan raja kepada orang yang berjasa bagi sang raja (Darmosoetopo, 1997). Kebijakan sosial kemasyarakatan lain yang dapat diketahui dari Prasasti Sindok adalah dikeluarkannya kebijakan-kebijakan penetapan sima yang ditujukan untuk pemeliharaan suatu fasilitas. Kebijakan Sindok yang semacam ini dapat ditemui pada Prasasti Turryān dan Kanuruhan, yang masing-masing menyebutkan penetapan sima bagi pemeliharaan bendungan serta kebun bunga. Karakteristik yang perlu menjadi perhatian pada kasus kebijakan Sindok adalah bahwa Sindok sangat sering mengeluarkan kebijakan melalui prasasti pada tahun 929 M, seakan-akan tahun itu sengaja menjadi tahun yang penting bagi program pembangunan yang didesain oleh Sindok.

Kebijakan Airlangga rupanya sedikit berbeda dengan kebijakan yang dikeluarkan oleh pendahulunya, yaitu Raja Sindok. Airlangga sama dengan Sindok, turut pula mengeluarkan kebijakan berupa sima punpunan dan sima makudur, hanya saja Airlangga lebih sering mengeluarkan kebijakan sima makudur selama dirinya berkuasa. Penetapan sima makudur bisa ditemukan di hampir seluruh prasasti yang dirinya keluarkan, sedangkan kebijakan sima punpunan hanya ditemukan di akhir masa kekuasaannya bahkan pada sampai masa pensiunnya. Kesamaan kebijakan yang dikeluarkan oleh Airlangga dengan Sindok juga dapat dilihat dari pembangunan Bendungan Waringin Sapta yang ia lakukan. Kebijakan Airlangga yang berlainan daripada Sindok adalah bahwa Airlangga selalu menyertakan kisah-kisah invasi atau peperangan yang ia lakukan selama masa kekuasaannya. Prasasti Pucangan merupakan prasasti yang merincikan penjelasan akan narasi ini. Narasi peperangan Airlangga juga kentara dari alasan anugrah yang Airlangga berikan kepada beberapa pihak sebagaimana yang tertera pada prasastinya.

Perbedaan gejala yang ditemui pada kasus ini dapat dihubungkan dengan konsep kehidupan setelah pralaya yang dipercaya oleh masyarakat Hindu-Buddha masa itu. 
Keterangan akan kepercayaan tersebut tersirat dari Prasasti Pucangan yang berbahasa Jawa Kuno sebagai berikut:

"tetapi karena ia seperti penjelmaan Dewa Wisnu, maka ia tidak bisa dibinasakan oleh kekuatan mahapralaya" (Susanti, 2010).

Prasasti ini mengisyaratkan bahwa masyarakat Hindu-Buddha pada masa itu mempercayai bahwa raja yang berkuasa atau selamat dari pralaya adalah penjelmaan Dewa Wisnu sendiri. Kepercayaan ini dapat ditarik garis merahnya dengan mitologi Wisnu-Anantasyin atau peranan Wisnu mengenai penciptaan dunia. Wisnu dipercaya oleh para golongan Waisnawa sebagai satu-satunya mahluk hidup yang bertahan dari kehancuran total pasca pralaya. Dewa Wisnu digambarkan mengapung bersama ananta (naga tempat Dewa Wisnu berbaring) di atas lautan tanpa batas yang diatapi oleh langit kosong yang gelap. Selama mengapung tersebut Wisnu tertidur selama ribuan tahun, hingga suatu kali tumbuh bunga teratai di pusarnya hingga muncullah Dewa Brahma. Dewa Brahma kemudian mulai menciptakan segala sesuatunya yang sebelumnya telah hancur karena pralaya.

Mitologi ini secara garis besar memberi kesan tegas bahwa Dewa Wisnu merupakan dewa dari segala dewa yang meliputi proses penciptaan, penghancuran/peleburan serta penciptaan. Secara garis besar Dewa Siwa dan Brahma dipandang sebagai perwujudan dari sang Wisnu sendiri (Liebert, 1976; Munandar, 2014). Penjelasan mitologi ini erat pula akan ekspektasi dari rakyat terhadap sang raja. Rakyat yang melihat raja sebagai "Wisnu" mereka tentu mengharapkan kebahagiaan setelah mengalami penderitaan pada masa pralaya. Raja dengan demikian perlu mengetahui keinginan sang rakyat sehingga mampu menguatkan kesan dirinya sebagai Wisnu sejati sebagaimana yang mereka inginkan. Rakyat perlu merasa bahwa dirinya seakan-akan telah memasuki masa kertayuga karena telah melewati zaman Kaliyuga. Fenomena kontrak sosial amat kentara pada tataran ini, khususnya pada posisi seorang raja perlu mengikuti general will (dalam hal ini kebahagiaan pasca-pralaya) dari rakyatnya untuk meraih legitimasi sebagai penjelmaan Dewa Wisnu.

Raja Sindok menyadari akan adanya fenomena ini melalui melalui mencitrakan dirinya sebagai seorang juru selamat dan pelihara atau dalam hal ini Dewa Wisnu sebagai pencipta serta pelindung. Menjadi masuk akal apabila Sindok kemudian berusaha membangun segala sesuatunya pada masa dirinya berkuasa, mengingat pralaya telah meluluhlantakkan fasilitas-fasilitas umum yang sebelumnya telah dibuat. Argumen ini menjadi lebih meyakinkan karena Sindok pada masa awal pemerintahannya sangat sering membangun fasilitas publik, terutama bangunan suci. Pembangunan bangunan suci menjadi aspek penting, karena kehancuran objek suci pada masa pralaya merupakan pertanda paling jelas akan pralaya itu sendiri (Schrieke, 2016). Pembangunan masif akan bangunan suci agaknya adalah upaya Sindok dalam membalik keadaan ini, selain juga memang terjadi destruksi besar-besaran bangunanbangunan suci di Jawa Tengah akibat gunung meletus. Sindok juga terkesan menunjukkan sisi "baik hati" nya melalui pembangunan bangunan-bangunan yang 
sebelumnya kurang diperhatikan oleh raja bagi rakyatnya, misalnya pembangunan kebun bunga atau bendungan. Upaya Sindok ini apabila diperhatikan melalui sudut pandang kontrak sosial, maka akan membentuk model kasual seperti pada Gambar 1.

Apabila Sindok lebih menunjukkan sifat pemelihara dan pembangunnya, maka Airlangga lebih mencitrakan Wisnu dalam dirinya sebagai penghancur para penjahat.

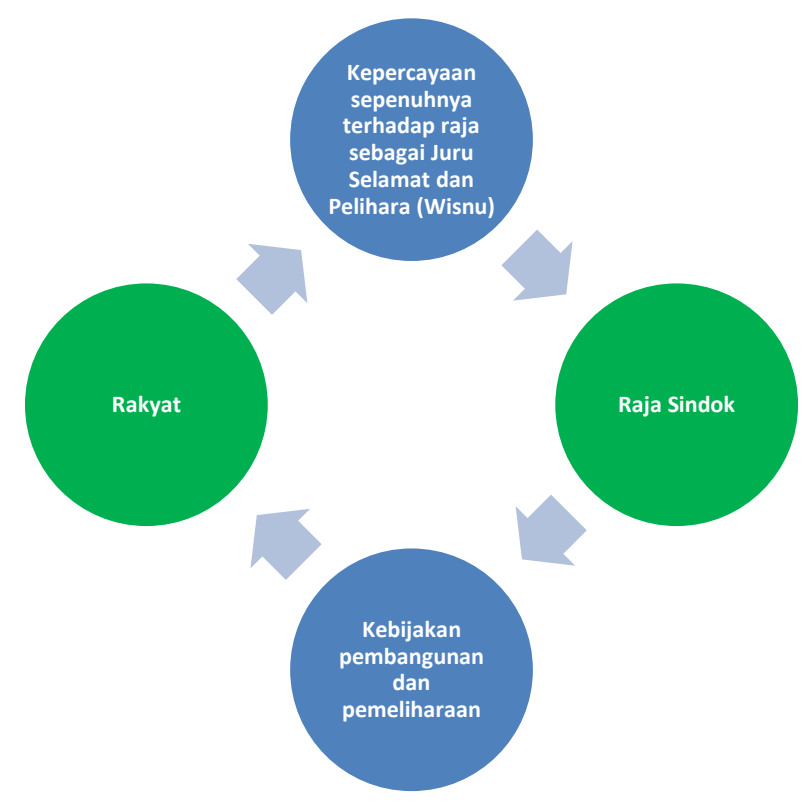

Gambar 1. Kontrak Sosial Kebijakan Raja Sindok (Sumber: bagan dibuat oleh penulis, 2020)

Gambaran Wisnu sebagai penghancur merujuk pada kisah tokoh Krisna pada epos Mahabharata sebagai penjelmaan Wisnu yang membunuh banyak raksasa perusak dunia. Wisnu dalam bentuk ini digambarkan dekat dengan purohita (golongan keagamaan). Paripurnanya tugas Wisnu di dunia melalui kembalinya Wisnu ke Suralaya (Schrieke, 2016) Apabila merujuk kepada peperangan yang disebut meluluhlantakkan tanah Jawa seperti yang disebut dalam Prasasti Pucangan, maka rakyat Jawa Kuno telah mengalami pula dampak negatif dari peperangan tersebut. Airlangga sebagai penghancur para penjahat tentu punya andil besar sebagai pelindung dunia. Pelindung dunia dalam konteks ini Airlangga dituntut untuk menjatuhkan "musuh-musuh" rakyat telah melakukan kegaduhan melalui pemberontakkan terhadap raja yang sah (Dharmawangsa Tguh). Pemberian anugrah sima terhadap para pejabat yang berjasa dapat diinterpretasikan sebagai bentuk murah hati Wisnu dalam tubuh Airlangga terhadap orang yang membantu "menyeimbangkan dunia". Proses menyingkirnya Airlangga dalam pertapaannya di bangunan suci dapat dianggap sebagai "kembalinya Wisnu ke Suralaya". Keterkaitan kebijakan Airlangga dengan general will dari rakyat dilihat dari sudut pandang kontrak sosial menghasilkan model kasual seperti pada Gambar 2. 


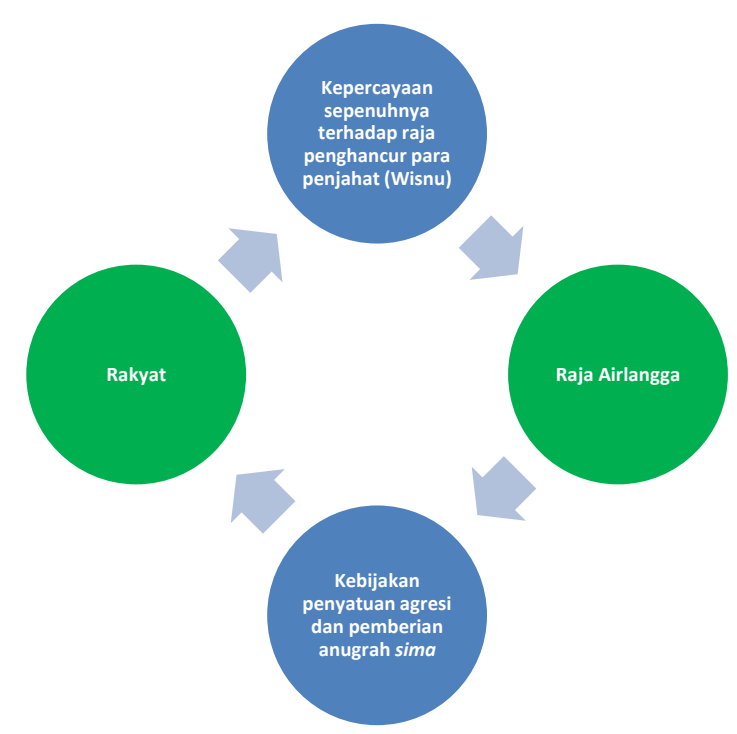

Gambar 2. Kontrak Sosial Kebijakan Raja Airlangga (Sumber: bagan dibuat oleh penulis, 2020)

Perbedaan dari pencitraan "Wisnu" dari kedua raja yang dibahas dalam kajian ini perlu pula diperhatikan lebih lanjut. Perbedaan pencitraan kedua raja ini agaknya berkaitan dengan dua aspek, antara lain: Pertama, bencana dari pralaya yang dialami oleh kedua raja bersumber dari masalah yang berbeda. Sindok menghadapi bencana yang sumbernya berasal dari fenomena alam, sehingga memang tidak banyak yang bisa dilakukan Sindok dalam menghadapi bencana tersebut secara represif kecuali dengan kebijakan pembangunan ulang. Kondisi ini amat berbeda dengan Airlangga yang menghadapi bencana yang bersumber dari perilaku manusia. Airlangga perlu melakukan kerja yang lebih keras untuk menghadapi bencana yang berkepanjangan (dalam hal ini peperangan). Airlangga seperti perlu menundukkan daerah-daerah yang memberontak agar pralaya tidak terus berlanjut; Kedua, aspek keabsahan kedua raja sebagai raja juga turut memengaruhi. Sindok memangku gelar sebagai seorang rakai hino, sedangkan Airlangga memangku gelar sebagai rakai halu. Boechari (2012b) menyebutkan bahwa rakai hino merupakan penguasa yang paling sah menggantikan raja karena statusnya yang setara dengan pangeran mahkota, sedangkan rakai halu berada di bawah posisi rakai hino. Sindok yang memangku gelar paling sah menggantikan raja sebelumnya tentu mendapat keuntungan besar dari gelarnya tersebut, sehingga tidak perlu melakukan tindakan penundukkan atau memang tidak pernah ada pemberontakan karena kesahannya. Airlangga menghadapi situasi yang berbeda karena gelarnya dan identitas genealogis yang dimilikinya (Susanti, 2010).

\section{SIMPULAN}

Arah kebijakan raja yang berkuasa pasca-pralaya dipengaruhi oleh macam bencana yang rakyat sebelumnya. Penentuan kebijakan perlu diselaraskan dengan bagaimana sang raja dapat mencitrakan dirinya sebagai Dewa Wisnu. Pencitraan 
tersebut bisa dengan menjelmakan diri sebagai penyelamat atau justru menjadi penghancur. Raja Sindok mencitrakan dirinya sebagai Dewa Wisnu yang bijak dalam menghadapi bencana alam pada masa awal kekuasaannya, sedangkan Airlangga memposisikan dirinya sebagai Dewa Wisnu yang ugra dalam menghancurkan para penjahat di dunia selama dirinya berkuasa. Fakta ini mengarahkan pada lebih ditakutinya bencana sosial dibandingkan dengan bencana alam pada masa lampau. Kebijakan Airlangga seakan dibuat lebih rumit dan berkepanjangan, dibandingkan dengan Sindok yang banyak mengeluarkan kebijakan di awal kekuasaannya. Pralaya atau bencana secara lebih lanjut dapat dimanfaatkan sebagai ajang bagi seorang raja dalam memperkuat legitimasinya.

\section{UCAPAN TERIMA KASIH}

Terima kasih saya ucapkan kepada Dr. Ninie Susanti Tedjowasono yang membimbing sekaligus memberikan masukan kepada saya selama penulisan naskah ringkas ini. Tidak lupa juga saya ucapkan terimakasih kepada Dian Sulityowati, M. Hum yang sedikit banyak mengenalkan saya pada teori-teori ekologi.

\section{DAFTAR PUSTAKA}

Andreastuti, Supriati. 2006. "Menelusuri kebenaran letusan Gunung Merapi 1006." Indonesian Journal on Geoscience 1 (4): 201-7. https://doi.org/10.17014/ijog.vol1no4.20064.

Bemmelen, R.W. van. 1949. The Geology of Indonesia. The Hague: Martinus Nijhoff.

Boechari. 2012a. "Rakryan Mahamantri i Hino: A study on the highest court dignitary of ancient Java up to the 13th century Ad." In Melacak Sejarah Kuno Indonesia lewat Prasasti, 115-34. Jakarta: Kepustakaan Populer Gramedia.

- 2012b. "Some Consideration on the Problem of the Shift of Mataram's Centre of Government from Central to East Java in the 10th Century." In Melacak Sejarah Kuno Indonesia lewat Prasasti, 155-82.

Brandes, Jan Laurens Andries. 1913. Oud-Javaansche Oorkonden: Negalaten Transcripties. Batavia: Albrecht \& Co.

Damais, L.C. 1955. "Études d'épigraphie indonésienne: Discussion de la date des incriptions." Bulletin de l'Ecole française d'Extrême-Orient.

Darmosoetopo, R. 1997. "Hubungan Tanah Sima dengan Bangunan Keagamaan di Jawa pada Abad IX-X M.” Universitas Gadjah Mada.

Djafar, Hasan. 2016. Prasasti Batu Pembacaan Ulang dan Alih Aksara I. Jakarta: Museum Nasional Jakarta. 
Economides, Neophitos. 2019. "The Theory of Social Contract and Legitimacy Today." Mediterranean Journal of Social Sciences 9 (5): 19-28. https://doi.org/10.2478/mjss-2018-0135.

Gibbon, Guy. 2013. Critically Reading the Theory and Methods of Archaeology: An Introductory Guide. Maryland: Rowman \& Littlefield Publishers.

Gonda, J. 1936. "Agastyaparwa." Bijdragen tot de Taal-, Land- en Volkenkunde van Nederlanche Indie VCIV: 223-85.

Liebert, Gosta. 1976. Iconographic Dictionary of the Indian Religions: Studies in South Asian Culture. Leiden: E.J. Brill.

Mascarenhas, Adolfo, dan Ben Wisner. 2012. "Politics: Power and disasters." In Handbook of Hazards and Disaster Risk Reduction, 48-60.

Moniz, Ariel. 2015. "The End of Days : Tales of Apocalypse Across Time and Space" 13 (Newman 19).

Munandar, A.A. 2014. "Mitos dan Peradaban Bangsa." In Mitra Satata: Kajian Asia Tenggara Kuna, 23-64. Jakarta: Wedatama Widyasastra.

Pardede, Rebecca Dewi Suryani. 1986. "Klasifikasi Sima: Sebuah Kajian Data Ukuran Tanah dari isi Prasasti-prasasti Masa Sindok sampai dengan Airlangga.” Universitas Indonesia.

Poesponegoro, Marwati Djoened, dan Nugroho Notosusanto. 2010. Sejarah Nasional Indonesia Jilid II: Zaman Kuno. Jakarta: Balai Pustaka.

Schrieke, B.J.O. 2016. Kajian Historis Sosiologis Masyarakat Indonesia: Penguasa dan Kerajaan Jawa pada Masa Awal. Yogyakarta: Penerbit Ombak.

Susanti, N. 2010. Airlangga: Biografi Raja Pembaharu Jawa Abad XI. Depok: Komunitas Bambu.

Wibowo, A.S. 2014. "Ratu Adil Jawa dan Ratu Filsuf Platon: Timbangan dan Aktualisasinya untuk saat ini." In Ratu Adil, Kuasa dan Pemberontakan di Nusantara, 14-43. Yogyakarta: Penerbit Ombak.

Witasari, V.H. 2009. "Prasasti Pucangan Sansekerta 959 Saka (suatu kajian ulang)." Universitas Indonesia.

Wurjantoro, E. 2018. Anugerah Sri Maharaja: Kumpulan Alihaksara dan alihbahasa Prasasti-prasasti Jawa Kuno dari Abad VII-XI. Depok: Departemen Arkeologi FIB UI.

\section{HASIL DISKUSI}

\section{Tidak ada pertanyaan}

